\title{
A Walk on the Wild Side: 2018 Cool-Season Forage Recommendations for Wildlife Food Plots in North Florida'
}

\author{
A. R. Blount, M. Wallau, H. K. Ober, E. Rios, J. M. B. Vendramini, J. C. B. Dubeux, Md. A. Babar, C. \\ L. Mackowiak, and K. H. Quesenberry ${ }^{2}$
}

Nationally, there is great interest in wildlife forages.

Florida's light and sandy soils, hot and humid summers, and seasonal droughts pose unique challenges for successful food plot plantings. We recommend using adapted varieties developed for Florida's particular growing conditions. We also suggest the use of forage blends to increase the plot's longevity and stability, and to supply variety to suit multiple wildlife components. It is important to soil test and apply fertilizer and/or lime based on the soil test report. Information on soil testing is available on EDIS at http://edis.ifas. ufl.edu/topic_soil_testing.

\section{Cool-Season Legumes}

Winter legumes are more productive and dependable in the heavier clay soils of northwest Florida or sandy soils that are underlain by a clay layer than in deep upland sands or sandy flatwoods. Overseeded white clover and ryegrass can grow successfully on certain flatwoods areas in northeast Florida. Inoculation of legumes is very important because it eliminates the need to supply nitrogen. Certain plants will manufacture nitrogen if the proper inoculant ( $R h i-$ zobium bacteria) is used. Many clovers and alfalfas come pre-inoculated. If the legumes you intend to use are not pre-inoculated, there are commercially available inoculants that are specific to each legume variety.

\section{Alfalfa}

This high-quality legume is usually grown as a winter annual in Florida. Several new varieties have been selected under grazing by cattle and are low-dormancy types. Low dormancy means that the alfalfa will sprout and grow in our mild winter climate. Many commercially available food plot blends include mid- or high-dormancy alfalfas that do not grow well in the southern US. Alfalfa requires a soil $\mathrm{pH}$ of 6.5-7.0, high soil fertility, and good management, making it difficult to manage in wildlife food plot situations. Recommended varieties are Bulldog 805 and Alfagraze 600RR.

1. This document is SS-AGR-28, one of a series of the Agronomy Department, UF/IFAS Extension. Original publication date April 2002. Revised November 2018. Visit the EDIS website at https://edis.ifas.ufl.edu for the currently supported version of this publication.

2. A. R. Blount, professor, Agronomy Department, UF/IFAS North Florida Research and Education Center; M. Wallau, assistant professor, Agronomy Department; H. K. Ober, associate professor, Department of Wildlife Ecology and Conservation, UF/IFAS NFREC; E. Rios, assistant professor, Agronomy Department; J. M. B. Vendramini, associate professor, Agronomy Department, UF/IFAS Range Cattle Research and Education Center; J. C. B. Dubeux, associate professor, Agronomy Department, UF/IFAS NFREC; Md. A. Babar, assistant professor, Agronomy Department; C. L. Mackowiak, associate professor, Department of Soil and Water Sciences, UF/IFAS NFREC; and K. H. Quesenberry, professor emeritus, Agronomy Department; UF/IFAS Extension, Gainesville, FL 32611.

The use of trade names in this publication is solely for the purpose of providing specific information. UF/IFAS does not guarantee or warranty the products named, and references to them in this publication do not signify our approval to the exclusion of other products of suitable composition.

The Institute of Food and Agricultural Sciences (IFAS) is an Equal Opportunity Institution authorized to provide research, educational information and other services only to individuals and institutions that function with non-discrimination with respect to race, creed, color, religion, age, disability, sex, sexual orientation, marital status, national origin, political opinions or affiliations. For more information on obtaining other UF/IFAS Extension publications, contact your county's UF/IFAS Extension office. 


\section{Arrowleaf Clover}

This is an annual clover that is similar to crimson clover in soil adaptation, management, and fertility requirements. It is mainly grown in heavier soils in northwest Florida. It is more productive than crimson clover in late spring. The recommended varieties are Blackhawk and Apache. Yuchi is more susceptible to virus than Blackhawk or Apache.

\section{Ball Clover}

This is an annual clover that grows on a wide range of soil types, including poorly drained soils. It is well-adapted, capable of reseeding readily, and considered an excellent clover for wildlife in Florida.

Recommended varieties are Don, Grazer's Select, and Segrest. Pre-inoculated seed is recommended.

\section{Berseem and Other Miscellaneous Clovers}

There are many other small-seeded clovers, including rose, berseem, hop, bur, and subterranean clover, which will work fairly well for wildlife food plots. Limited local seed availability or high seed costs may be limiting factors. Generally, these clovers produce less forage than crimson, white, arrowleaf, and red clover and have a short growing season. Ball, Persian, and hop clovers reseed well. Recommended varieties include Bigbee and Frosty berseem, Armadillo medic, Devine Little Bur, and Overton rose clovers.

\section{Red Clover}

This clover behaves as a winter annual under most north Florida conditions. Some reseeding may occur. Nondormant (or low-dormancy) varieties are recommended. Red clover does not tolerate flooding. Recommended varieties are Southern Belle, Bulldog Red, Barduro, and Red Ace. Southern Belle and Barduro were developed in Florida. FL2,4-D is a new 2,4-D herbicide-resistant red clover, released by UF/IFAS in 2016. Seed of the 2,4-D red clover is not expected to be commercially available until at least fall of 2019, but herbicide resistance would be beneficial in mixed wildlife plantings for broadleaf weed control.

\section{Crimson Clover}

This is a well-adapted legume for north Florida. It is an excellent forage producer and can reseed itself each year if weather conditions permit. It is an annual clover that is adapted to fertile, well-drained soil. Of the clovers, it appears to be the least sensitive to soil $\mathrm{pH}$. It has a relatively short grazing season, so it may be grown in combination with ryegrass, clovers, or a small grain crop to extend the period of forage availability. Recommended varieties are Dixie and AU-Robin; however, seed of AU-Robin may be in short supply in 2018.

\section{Vetch}

Vetch grows best in well-drained, fertile, loamy soils. It has a spreading, viny growth habit and is an annual plant. The plant reseeds itself fairly well. Many wildlife species consume the seed and foliage. Recommended varieties are Hairy, Cahaba White, and Merit. Commercial seed production of certain vetch varieties may be limited in 2018 .

\section{White Clover}

White clover in Florida is usually a winter annual, but it may act as a short-term perennial under optimal fertility and moisture conditions. It is adapted to moist soils throughout Florida and reseeds well. Nematodes and other pests can limit production. Recommended varieties are Ocoee and Osceola, Louisiana S-1, Barblanca, Regalgraze, and Regal Ladino. Durana is also well-adapted, having a prostrate growth habit and longevity.

\section{Winter Peas}

This annual legume is best suited to well-drained soils with high clay content. They typically are not very cold-hardy. Austrian, Whistler, and Maple are recommended varieties. Several new varieties are commercially available and may be well-suited for wildlife food plots in this region, but these have not been broadly evaluated.

\section{Cool-Season Grasses}

Cool-season grasses generally include ryegrass and the small grains: wheat, oats, rye, and triticale (a man-made cross of wheat and rye). These grasses provide excellent winter forage and a spring seed crop which wildlife readily utilize.

\section{Oats}

Oats may be planted and grazed by wildlife earlier than rye. When seeded in mid-fall, they should produce very palatable forage by late fall. Oats are not as cold-hardy as rye or wheat and may be susceptible to freeze injury. It is important to choose recommended oat varieties. Many feed oats are sold and planted as seed oats, but they often do not have a guarantee on the percent germination. Feed oats also may not have any resistance to the heavy disease pressure in Florida, particularly from rust and virus. Recommended varieties include "Big Boss" Wildlife Forage Oat, Horizon 306, Horizon 720, Plot Spike LA 9339, Ram LA99016, Legend 567, and Buck Forage. Legend 567, Horizon 720, 
Horizon 306, Big Boss Wildlife Oat, Buck Forage, and Ram Oat have improved crown rust resistance, winter hardiness, and good grain and forage production for wildlife interests in our area.

\section{Rye}

Rye is widely used for winter grazing for cattle, but it may be grazed by deer as well. Rye is more cold-tolerant than oats and generally produces more forage than either oats or wheat. Rye should not be planted as early as oats due to several disease problems occurring in the early fall. It is best to wait for cool weather before planting. Recommended varieties are FL 401 (for early grazing or for use in blends), Kelly Grazer III (FL 104), Wrens Abruzzi, Bates RS4, Elbon, Oklon, Maton, and Maton II. Other commercial varieties may be adapted but have not been included in our variety trials in recent years.

\section{Wheat}

Wheat is excellent for wildlife. The forage is grazed by deer, and birds utilize the seed. Recommended varieties are AGS 2024, AGS GrazeAll (AGS2027), AGS 2033, AGS 2038, Dyna-Gro Savoy, Pioneer 26R10, Pioneer 26R41, and Pioneer 26R94. Hessian fly resistance is important in wheat, particularly during early planting as wildlife forage. Coker 9553, Roberts, and GA-Gore are susceptible to Hessian fly and are no longer recommended.

\section{Ryegrass}

Ryegrass is a valuable and hardy forage crop for use on flatwoods soils or the heavier sandy loam soils in northwest Florida. In wildlife food plots, ryegrass may become a weedy problem and dominate the food plot. Ryegrass also has a tendency to reseed and may germinate the following year. There are many well-adapted ryegrass varieties on the commercial market. However, we generally do not recommend their use in wildlife food plot mixes.

\section{Triticale}

This is a very high-quality, robust small grain that resulted from a cross of wheat and rye. It is very well-adapted to north Florida, has good disease and insect resistance, and grows well even when late-planted in December and January. Seed availability may be limited in 2018 because seed production was difficult this past season. Recommended varieties include Trical 342 and Monarch.

\section{Brassica and Forage Chicory Crops}

Brassicas are annual crops which are highly productive and digestible and can provide forage as quickly as 40 days after seeding, depending on the species. Forage brassica crops such as turnip, swede, rape, and kale can be both fall- and spring-seeded. Little is known about the adaptability of forage brassicas to Florida or the acceptability as a food source for wildlife.

\section{Kale (Brassica oleracea L. acephala group)}

Kale is very winter-hardy. Varieties include Premier, Vates, and Siberian.

\section{Rape (Brassica napus L.)}

This would also be considered to be very winter-hardy. Varieties include Rangi, Rangiora, Barnapoli, Dwarf Essex, Emerald, and Winfred.

\section{Turnip (Brassica rapa L.) or Turnip Hybrids}

These crops grow very quickly, reaching near maximum production levels in 80-90 days. Varieties include Purple Top, White Globe, and Barkant. Some varieties such as All Top and Seven Top only produce tops.

\section{Swede (Brassica napus L.)}

Like turnip, swedes produce a large edible root. Yields are higher than those of turnip; however, these grow slower and require $150-180$ days to reach maximum production.

\section{Daikon Radish (Raphanus sativus)}

This is a highly palatable brassica that is well-adapted to light, sandy soils. It is often referred to as tillage radish. Early planting may cause early bloom. Consider staggered planting dates to encourage longer season availability. Recommended varieties are Trophy and Daikon radish.

\section{Forage Chicory (Cichorium intybus L.)}

This is a perennial plant (forb) that is suited to well-drained or moderately drained soils with medium to high fertility levels and a $\mathrm{pH}$ of 5.5 or greater. Varieties available at this time are Puna and Forage Feast. 


\section{Recommended Cool-Season \\ Forage Blends}

Use recommended varieties listed above and inoculate clovers with proper Rhizobium bacteria. Crimson clover is better adapted to well-drained sites, red clover to mediumdrained sites, and white and arrowleaf clover to wet or poorly drained sites.

\section{Best Value}

- $50 \mathrm{lb}(2 \mathrm{bu})$ oats

- $50 \mathrm{lb}(1 \mathrm{bu})$ wheat or triticale

- $6 \mathrm{lb}$ red clover

- $15 \mathrm{lb}$ crimson clover

\section{Double Treat}

For well-drained sites:

- $10 \mathrm{lb}$ red clover

- $15 \mathrm{lb}$ crimson clover

\section{Triple Treat}

For wet or poorly drained sites:

- $4 \mathrm{lb}$ white clover

- $12 \mathrm{lb}$ red clover

- $4 \mathrm{lb}$ arrowleaf clover

\section{Tetra Treat}

For medium-drained to wet sites:

- $15 \mathrm{lb}$ crimson clover

- $6 \mathrm{lb}$ red clover

- $4 \mathrm{lb}$ arrowleaf clover

- $2 \mathrm{lb}$ white clover 
Table 1. Planting dates, seeding rates, planting depths, and grazing parameters for certain cool-season forage crops.

\begin{tabular}{|c|c|c|c|c|c|c|}
\hline \multirow[t]{2}{*}{ Seed-Propagated Crops ${ }^{1}$} & \multirow[t]{2}{*}{ Planting Dates ${ }^{2}$} & \multirow{2}{*}{$\begin{array}{l}\text { Seeding Rates } \\
\text { (Ib/A broadcast) }\end{array}$} & \multirow{2}{*}{$\begin{array}{l}\text { Seeding } \\
\text { Depth (in) }\end{array}$} & \multicolumn{2}{|c|}{ Grazing Height (in) } & \multirow{2}{*}{$\begin{array}{l}\text { Rest Period } \\
\text { (days) }\end{array}$} \\
\hline & & & & Beginning & End & \\
\hline Alfalfa & Oct. 1-Nov. 15 & $15-20$ & $1 / 4-1 / 2$ & $10-16$ & $3-4$ & $\begin{array}{l}\text { Hay: } 35-40 \\
\text { Grazing: } 15-30\end{array}$ \\
\hline Clover, Arrowleaf & Oct. 1-Nov. 15 & $8-12$ & $0-1 / 2$ & $8-10$ & $3-5$ & $10-20$ \\
\hline Clover, Ball & Oct. 1-Nov. 15 & $2-3$ & $0-1 / 4$ & $6-8$ & $1-3$ & $7-15$ \\
\hline Clover, Berseem & Oct. 1-Nov. 15 & $15-20$ & $1 / 4-1 / 2$ & $8-10$ & $3-5$ & $10-20$ \\
\hline Clover, Crimson & Oct. 1-Nov. 15 & $20-25$ & $1 / 4-1 / 2$ & $8-10$ & $3-5$ & $10-20$ \\
\hline Clover, Red & Oct. 1-Nov. 15 & $10-15$ & $1 / 4-1 / 2$ & $8-10$ & $3-5$ & $10-20$ \\
\hline Clover, Subterranean & Oct. 1-Nov. 15 & $15-20$ & $1 / 4-1 / 2$ & $6-8$ & $1-3$ & $7-15$ \\
\hline Clover, White & Oct. 1-Nov. 15 & $3-4$ & $0-1 / 4$ & $6-8$ & $1-3$ & $7-15$ \\
\hline Fescue, Tall & Nov. 1-Dec. 15 & $20-25$ & $1 / 4-1 / 2$ & $4-8$ & $2-3$ & $15-30$ \\
\hline Medic & Oct. 1-Nov. 15 & $\begin{array}{l}10-15 \\
\text { (rates differ) }\end{array}$ & $0-1 / 4$ & $6-8$ & $1-3$ & $7-15$ \\
\hline Oats for forage & Sept. 15-Nov. 15 & $100-120$ & $1-2$ & $8-12$ & $3-5$ & $7-15$ \\
\hline Pea, Austrian Winter & Oct. 1-Nov. 15 & $40-60$ & $1 / 2-1$ & \multicolumn{3}{|c|}{$\begin{array}{l}\text { Poor grazing tolerance. Better suited as a hay or } \\
\text { silage crop. }\end{array}$} \\
\hline Rye for forage & Oct. 15-Nov. 15 & $90-120$ & $1-2$ & $8-12$ & $3-4$ & $7-15$ \\
\hline Ryegrass, Italian (annual) & Oct. 1-Nov. 15 & $20-30$ & $0-1 / 2$ & $6-12$ & $3-4$ & $7-15$ \\
\hline Sweetclover & Oct. 1-Nov. 15 & $10-15$ & $1 / 4-1 / 2$ & $8-10$ & $3-5$ & $10-20$ \\
\hline Turnips & Oct. 1-Nov. 15 & $5-6$ & $1 / 4-1 / 2$ & $6-8$ & $2-3$ & varies \\
\hline Vetch, hairy & Oct. 1-Nov. 15 & $20-30$ & $1-2$ & $6-8$ & $3-4$ & varies \\
\hline Wheat for forage & Oct. 15-Nov. 15 & $90-120$ & $1-2$ & $8-12$ & $3-5$ & $7-15$ \\
\hline $\begin{array}{l}\text { Triticale for silage or use in } \\
\text { blends }\end{array}$ & Oct. 15-Nov. 15 & $90-120$ & $1-2$ & \multicolumn{3}{|c|}{$\begin{array}{l}\text { Harvest for silage at milk or soft dough stage of } \\
\text { maturity. }\end{array}$} \\
\hline
\end{tabular}

